\title{
Kecakapan Lulusan Pendidikan Tinggi Teologi Menghadapi Kebutuhan Pelayanan Gereja dan Dunia Pendidikan Kristen
}

Gidion

Sekolah Tinggi Teologi Kristus Alfa Omega, Semarang, Jawa Tengah, Indonesia gideonjosila@gmail.com

\begin{tabular}{|c|c|}
\hline & \\
\hline Arti & oftenly complained about the \\
\hline $\begin{array}{l}\text { Submitted: } \\
22 \text { February } 2020\end{array}$ & $\begin{array}{l}\text { low skills possessed by the graduates. Ine same thing is experienced in the } \\
\text { world of church service and Christian education, that there are still many }\end{array}$ \\
\hline & ll scholars who lack the skills or expertise in their fields. This study \\
\hline $\begin{array}{l}\text { 24 March } 2020 \\
\text { Acceted: } \\
21 \text { April } 2020\end{array}$ & $\begin{array}{l}\text { aimed to determine how well the graduates of theological college having skills } \\
\text { which answer the needs in the Church and Christian educational institutions. }\end{array}$ \\
\hline Keywe & ess- \\
\hline & $\begin{array}{l}\text { ment, namely skill of leadership, servants, service experience, theological } \\
\text { knowledge, and English ability. }\end{array}$ \\
\hline Christian & \\
\hline $\begin{array}{l}\text { education; } \\
\text { soft skills; } \\
\text { theological } \\
\text { college; }\end{array}$ & $\begin{array}{l}\text { Abstrak: Para pengguna lulusan perguruan tinggi mengeluhkan masih } \\
\text { rendahnya kecakapan yang dimiliki oleh para lulusan terebut. Hal serupa juga } \\
\text { dialami dalam dunia pelayanan gereja dan pendidikan Kristen, bahwa masih }\end{array}$ \\
\hline $\begin{array}{l}\text { kecakapan lulusan; } \\
\text { pelayanan gereja; } \\
\text { pendidikan }\end{array}$ & $\begin{array}{l}\text { banyak sarjana teologi yang kurang memiliki kecakapan atau keahlian dalam } \\
\text { bidangnya. Penelitian ini bertujuan untuk mengetahui seberapa baik kecakapan } \\
\text { lulusan STT dalam menjawab kebutuhan pelayanan di gereja dan lembaga }\end{array}$ \\
\hline Kris & $\begin{array}{l}\text { pendidikan Kristen. Hasil penelitian menyimpulkan bahwa kecakapan lulusan } \\
\text { STT masih belum maksimal. Ada lima kecakapan yang memiliki penilaian yang }\end{array}$ \\
\hline $\begin{array}{l}\text { DO1: https://doi.org/ } \\
\text { 10.30995/kur.v6il.144 }\end{array}$ & $\begin{array}{l}\text { cukup rendah yaitu kecakapan sebagai pemimpin, sebagai pelayan, pengalaman } \\
\text { pelayanan, pengetahuan teologi, dan kemampuan berbahasa Inggris. }\end{array}$ \\
\hline
\end{tabular}

\section{Pendahuluan}

Gereja dan lembaga pendidikan Kristen adalah dunia kerja bagi para lulusan pendidikan tinggi Teologi. Kebutuhan Gereja dan lembaga pendidikan Kristen amat besar setiap tahunnya, bagi para lulusan dari Sekolah Tinggi Teologi (STT). Berdasarkan survei awal, tampak beberapa Gembala Sidang Gereja besar di daerah jawa barat mendatangi salah satu STT di Semarang untuk mencari Mahasiswa sesuai dengan kualifikasi yang mereka butuhkan. Menariknya setelah proses pencarian itu berakhir, sang Pendeta mengatakan sulit mencari Mahasiswa yang sesuai dengan kriteria ideal mereka. Pada kesempatan yang berbeda, salah satu STT di Semarang mengadakan pertemuan antara pimpinan perguruan tinggi teologi dengan para pengguna lulusan. Pertemuan ini diagendakan untuk mendengarkan masukan dari para pengguna lulusan tentang kecakapan para lulusan STT tersebut. Pertemuan itu menghasilkan beberapa catatan penting yang menunjukkan bahwa para pengguna lulusan belum puas dengan kualitas para lulusan. 
Permasalahan tentang kecakapan lulusan ternyata berimbas pada adanya beberapa lulusan yang menjadi pengangguran terdidik. Berdasarkan survei awal, tampak bahwa ada lulusan dari salah satu STT di Semarang yang mengalami kesulitan untuk menjadi pelayan tetap di suatu gereja. Hal yang disayangkan lagi adalah, bahwa STT yang diamati ini tidak memiliki data yang lengkap tentang pelayanan para lulusannya. Diduga bahwa tidak semua pimpinan perguruan tinggi Teologi mengerti pentingnya data pekerjaan atau pelayanan para lulusan, sebagai data evaluasi. Namun demikian dari contoh kasus di atas dapat diduga bahwa pengangguran terpelajar tidak hanya pada lulusan bidang ilmu umum, tetapi juga pada lulusan bidang ilmu Teologi. Pengangguran terdidik menjadi cambuk bagi pendidikan tinggi Teologi dalam menjawab kebutuhan masyarakat. Pendidikan tinggi Teologi juga berupaya agar lulusannya menjadi pelayan Tuhan yang berguna di Gereja, dunia pendidikan Kristen dan masyarakat secara umum dalam menjawab permasalahan yang ada di masyarakat sesuai dengan bidang keilmuannya. Namun demikian masih ditemukan lulusan pendidikan tinggi Teologi yang kemudian bekerja fulltime di pabrik, pertokoan, sebagai pedagang dan bidang usaha lainnya.

Jansen Sinamo mengatakan bahwa kesempatan kerja sebenarnya tidak terbatas jumlahnya. ${ }^{1}$ Iklan lowongan kerja berbiaya mahal terus saja tampil di koran dan majalah, juga media online. Biro-biro tenaga kerja dan agen-agen perekrutan eksekutif selalu sibuk mengurusi kebutuhan pasar Sumber Daya Manusia (SDM) yang terus meningkat. Sinamo menambahkan, bahwa hampir pasti kesempatan bekerja di dunia kerja masih berpeluang besar. Namun dapat hampir dipastikan juga bahwa kebutuhan SDM dalam dunia kerja kerja tidak akan terpenuhi secara memuaskan. Dengan demikian bukan jumlah atau jenis pekerjaan yang sedikit jumlahnya, tetapi jumlah pekerja bermutulah yang kurang memadai. Pertanyaanya, mengapa fenomena ini terjadi pada lulusan terdidik? Menurut Sinamo, karena pendidikan dan pelatihan kerja di dunia pendidikan terbukti masih jauh dari harapan mengahasilkan SDM berkualitas seperti yang dituntut dunia kerja yang standarnya terus bergerak naik. ${ }^{2}$ Dinamika perkembangan di dunia pelayanan Gereja dan lembaga pendidikan Kristen seharusnya diikuti oleh perkembangan pendidikan di Sekolah Tinggi Teologi, sehingga lulusan menjadi produk tepat guna dalam menjawab kebutuhan pelayanan gereja dan lembaga pendidikan Kristen hari ini.

Pendidikan teologi dalam penelitian ini adalah Sekolah Tinggi Teologi (STT), yaitu suatu institusi pendidikan bagi calon pemimpin gereja atau lembaga-lembaga rohani. Sebagai institusi pendidikan tinggi, pelaksanaan pendidikan mengacu pada UU RI No. 20 Tahun 2003 tentang sistem pendidikan nasional:

Pendidikan adalah usaha sadar dan terencana untuk mewujudkan suasana belajar dan proses pembelajaran agar peserta didik secara aktif mengembangkan potensi dirinya un-tuk memiliki kekuatan spiritual keagamaan, pengendalian diri, kepribadian, kecerdasan, akhlak mulia, serta ketrampilan yang diperlukan dirinya, masyarakat, bangsa, dan negara.

Dari UU ini dapat dipahami bahwa pendidikan adalah wadah yang berguna untuk mempersiapkan peserta didik menjadi pribadi yang berguna bagi dirinya sendiri, masyarakat, bangsa dan Negara.

5.

${ }^{1}$ Jansen Sinamo, Teologi Kerja Modern \& Etos Kerja Kristiani (Jakarta: Institut Darma Mahardika, 2011),

${ }^{2}$ Ibid., 6. 
Setiap Perguruan Tinggi (PT) tentunya memiliki tujuan yang jelas dan terukur dalam mencetak kompetensi lulusannya. Profil lulusan menjadi target dan arah pengembangan peserta didik selama menempuh pendidikan di bangku PT. Profil lulusan PT ditetapkan melalui banyak tahapan, dan melibatkan berbagai unsur yang berkaitan dengan pengelola/pelaksana dan pengguna lulusan. Hal ini dilakukan, agar pelaksanaan pembelajaran di Perguruan Tinggi betulbetul menjawab kebutuhan pengguna, dan sesuai dengan visi misi Institusi Perguruan Tinggi.

Keberhasilan suatu PT dapat dilihat dari seberapa baik PT tersebut menghasilkan kualitas dan kuantitas lulusan yang sesuai dengan profil lulusan, yang tentunya menjawab kebutuhan pengguna (stakeholder). Profil lulusan yang telah ditetapkan oleh program studi menjadi kompas pelaksanaan pendidikan di prodi. Pencapaian profil lulusan dapat dilihat dari uraian kurikulum program studi, selain itu adanya integrasi kegiatan penelitian dan pengabdian masyarakat yang dilakukan oleh mahasiswa. Berdasarkan survey awal diketahui bahwa kurikulum program studi belum tersertifikasi Kualifikasi kurikulum berbasis KKNI, sehingga masih ada mata kuliah yang belum terlihat jelas kontribusinya pada pencapaian profil lulusan prodi. Pada item borang akreditasi, disebutkan bahwa salah satu alat ukur keberhasilan Perguruan Tinggi adalah dengan melihat waktu tunggu para lulusan masuk ke dunia kerja. Yang dimaksud dengan waktu tunggu adalah rentang waktu antara waktu kelulusan ke waktu diterima bekerja. Semakin lama para lulusan masuk ke dunia kerja, maka diindikasikan bahwa perguruan tinggi belum maksimal dalam menjalankan fungsinya sesuai UU.

Perguruan Tinggi yang telah mendapatkan kepercayaan publik berkat kehandalan kualitasnya, tentu memiliki waktu tunggu yang pendek bagi lulusannya memasuki dunia kerja. Namun Perguruan Tinggi yang belum memiliki nama besar atau pengakuan masyarakat, perlu memahami dengan baik apa saja dibutuhkan dunia kerja dari para lulusan Perguruan Tinggi? Dan strategi apa yang perlu dilakukan untuk mengurai atau memecahkan permasalahan kebutuhan dunia kerja tersebut? Kedua pertanyaan ini adalah focus dari penelitian ini.

Kellerman dan Sagmeister mengatakan bahwa permasalahan lulusan dalam menghadapi dunia kerja, salah satunya disebabkan oleh kesenjangan yang besar antara kompetensi yang disiapkan Perguruan Tinggi pada mahasiswa dengan kompetensi yang menjadi kebutuhan dunia kerja. ${ }^{3}$ Kebutuhan dunia kerja adalah apa yang diharapkan dunia kerja, dari para luluasan Perguruan Tinggi yang akan memasuki dunia kerja. Secara umum kesiapan lulusan untuk memasuki dunia pelayanan melibatkan tiga faktor, yaitu: (1) fisiologis yang menyangkut kematangan usia, kondisi fisik, dan organ tubuh, (2) pengalaman yang meliputi pengalaman belajar dan bekerja menyangkut pengetahuan dan keterampilan (hard skill), dan (3) psikologis yaitu keadaan mental, emosi, dan sosial (soft skill). ${ }^{4}$ Ketiga faktor ini memiliki andil yang besar dalam menentukan kesiapan lulusan menjadi pelayan yang sanggup menjawab kebutuhan pelayanan di Gereja dan lembaga pendidikan Kristen.

Berdasarkan survei awal ditemukan untuk menemukan data yang menggambarkan hal-hal penting yang menjadi kebutuhan dari para pengguna lulusan Sekolah Tinggi Teologi, namun

${ }^{3}$ Kellermann P and G Sagmeister, "Higher Education and Graduate Employment in Austria," European Journal of education 35, no. 2 (2000): 8.

${ }^{4}$ Sutrisno Didik Suryanto, Waras Kamdi, "Relevansi Soft Skill Yang Dibutuhkan Dunia Kerja Dengan Yang Dibelajarkan Di Sekolah Menengah Kejuruan,” Jurnal Teknologi dan Kejuruan 36, no. 2 (2013): 108. 
nampaknya belum pernah ada data riset yang telah dipublikasikan tentang hal ini. Hal inilah yang menjadi alasan bagi peneliti untuk coba mengukur hal-hal apa sajakah yang dibutuhkan oleh para pengguna lulusan dari lulusan STT. Hal-hal pokok yang menjadi kebutuhan dunia kerja secara umum menjadi rujukan dalam menemukan hal-hal pokok yang menjadi kebutuhan dari para pengguna lulusan. Selain itu dunia usaha dan pelayanan gereja sama-sama membutuhkan tenaga kerja yang cakap/terampil dan berkepribadian baik, maka hasil riset tentang kebutuhan dunia kerja dalam dunia usaha digunakan sebagai sumber informasi.

Pada dasarnya kebutuhan dunia kerja dapat dilihat dari data rasio kebutuhan hard skill (pengetahuan dan keterampilan) dan soft skill (sikap/kepribadian). Sailah dalam temuan risetnya menyimpulkan bahwa rasio kebutuhan soft skill di dunia kerja adalah $80 \%$, dan hard skill adalah $20 \%$. Orang yang berhasil di dunia usaha adalah mereka yang memiliki mind set yang lebih baik, daripada technical skillnya. ${ }^{5}$ Dalam penelitian ini, pengukuran dilakukan pada halhal pokok yang disebut sebagai bentuk hard skill dari lulusan STT, dan juga hal-hal pokok yang disebut sebagai bentuk soft skill dari lulusan STT. Adapun yang dimaksud STT dalam penelitian ini adalah STT Kristus Alfa Omega yang ada di Jawa Tengah. STT ini memiliki pengelolaan yang legal dan baik, hal itu dibuktikan dari hasil akreditasi Institusinya dan seluruh program studi yang ada juga telah terakreditasi semuanya. Lulusan yang menjadi subyek riset atau yang diamati adalah lulusan yang sedang melakukan praktek pelayanan tahunan yang bertugas di beberapa wilayah seperti: Toraja, Samarinda, Maluku, Medan, Kalimantan Barat, Jakarta, Surabaya, Magelang dan Semarang.

\section{Kecakapan Lulusan}

Topik utama penelitian ini adalah kecakapan kerja para lulusan, oleh sebab itu penting untuk melihat apa yang Alkitab jelaskan tentang teologi kerja. Sinamo menjelaskan bahwa kerja adalah kegiatan yang memiliki tujuan dan melibatkan energi mental, emosional dengan dibayar atau tidak. ${ }^{6}$ Ada banyak bukti Alkitab yang menegaskan bahwa Allah adalah sang pekerja yang Agung. Dalam Kitab yang pertama (Kejadian), Allah ditunjukkan bekerja selama enam hari untuk menciptakan dengan baik dan indah semua alam semesta (Kej. 1-2). Bahkan dalam nyanyian Mazmur disebutkan bahwa Allah tidak pernah terlelap dan tertidur, Allah menjaga keluar masuk umatNya dari dulu sampai sekarang (Maz. 121:4,8). Tuhan Yesus juga berkata bahwa Bapa di sorga bekerja hingga sekarang, dan Tuhan Yesus juga menegaskan bahwa diriNya juga terus bekerja (Yoh. 5:17). Beberapa petikan bagian Alkitab memberikan informasi bahwa Allah adalah Allah yang bekerja, yang bekerja sejak awal sebelum adanya penciptaan, masa penciptaan, dan masa pelayanan Tuhan Yesus di bumi, dan dijelaskan sampai saat ini pun Allah diterangkan masih tetap bekerja.

Allah yang adalah sang pekerja Agung, telah mencitakan manusia menurut gambar dan rupa Allah (Kej. 1:26-27). Dengan demikian, manusia memiliki hakekat yang sama dengan Allah yaitu hakekat bekerja. Jansen Sinamo berkata bahwa manusia yang tidak mau bekerja bukanlah manusia yang segambar dengan Allah. Jadi manusia yang bekerja dengan sebaik-

\footnotetext{
${ }^{5}$ Ibid., 109.

${ }^{6}$ Jansen Sinamo, Teologi Kerja Modern \& Etos Kerja Kristiani, 7.
} 
baiknya adalah manusia yang mencerminkan dirinya segambar dengan Allah. ${ }^{7}$ Allah menciptakan manusia bukan tanpa tujuan, Allah menghendaki manusia menjadi rekan kerja Allah dalam hal bekerja mengelola bumi. Jadi karena salah satu hakikat Allah adalah kerja, maka kita yang disebut diciptakan segambar dan serupa dengan Allah juga memiliki hakikat yang sama yaitu bekerja.

Beberapa prinsip kerja yang dijelaskan Alkitab adalah: pertama, motivasi bekerja adalah belas kasihan. Tuhan Yesus telah mencontohkan bahwa yang menjadi motivasinya bekerja di bumi memberitakan Injil dari satu tempat ke tempat lainnya adalah belas kasihan (Mat. 14:4). Kedua, bekerja dengan berfokus pada apa yang ditugaskan. Tuhan Yesus mengemban tugas besar yaitu untuk menghadirkan Kerajaan Allah. Tuhan Yesus terus berfokus terus pada tugas itu, sekalipun Tuhan Yesus menggunakan tubuh manusia yang merasakan kesakitan, penderitaan, hina, dan semua yang sangat mungkin untuk mengalihkan fokusnya pada tugas yang diberikan oleh Bapa di Surga. Tuhan Yesus tetap berfokus pada tugas yang diberikan kepadaNya, dan menuntaskannnya dengan sempurna. Ketiga, pekerjaan adalah panggilan mulia untuk melayani. Setiap bidang kerja dimana kita bekerja adalah tempat dimana Tuhan memanggil kita untuk melayani dan menjadi terang Tuhan yang bersinar. Keempat, bekerja untuk menghadikan kerajaan Allah di dunia kerja.

Kelima, bekerja juga salah satu bentuk ber-ibadah kepada Allah. Ibadah dalam konsep Alkitab adalah mempersembahkan seluruh tubuh bagi Allah (Rom. 12:1). Ayat ini menjelaskan bahwa makna ibadah yang sebenarnya adalah menggunakan seluruh bagian tubuh untuk melakukan segala hal yang kudus di segala tempat (termasuk tempat bekerja), inilah ibadah yang sejati. Ibadah juga berarti memuliakan nama Tuhan. Tuhan Yesus setelah bekerja di bumi selalu berkata "Aku telah mempermuliakan Engkau di bumi dengan menyelesaikan pekerjaan yang engkau berikan kepadaKu" (Yoh. 17:4). Jadi, mengerjakan pekerjaan untuk memuliakan Tuhan adalah ibadah. Keenam, bekerja dengan penuh seni dan kreativitas yang cerdas. Orang banyak terpukau dengan cara Yesus mengajar, karena Tuhan Yesus menggunakan kata-kata yang indah (Luk. 4:22). Selain berkemampuan estetika yang baik, Tuhan Yesus juga cerdas dan kreatif dalam memilih cara menyapikan pesannya, sehingga banyak orang yang terheran dengan kecerdasannya (luk. 2:47). Ketujuh, bekerja adalah pelayanan dengan kerendahan hati.

Yorke dan Knight menjelaskan bahwa setiap lulusan yang ingin masuk dunia kerja perlu memiliki kecakapan kerja yang baik, yang diantaranya adalah keterampilan kerja, pemahaman, dan atribut personal yang mendukung lulusan diterima di dunia kerja dan menjadi sukses. ${ }^{8}$ Yorke juga menjelaskan bahwa lulusan yang memiliki kemampuan yang baik sanggup memilih keputusan yang efektif, mampu mnguraikan tujuan yang ingin dicapai, cakap membangun kerjasama dengan rekan kerja, dan dapat secara terus menerus melakukan pengembangan diri dalam masyarakat yang beragam dan dinamis. ${ }^{9}$ Kecakapan kerja seperti yang dijelaskan di atas adalah kecakapan kerja yang diperlukan pelayanan di Gereja dan lembaga pendidikan Kristen dari para lulusan STT.

\footnotetext{
${ }^{7}$ Ibid., 18.

${ }^{8}$ Mantz Yorke and Peter T. Knight, "Curricula for Economic and Social Gain," Higher Education (2006): 565-568.

${ }^{9}$ Ibid., 568.
} 
Kardimin dalam bukunya mengatakan bahwa terdapat dua factor yang mempengaruhi kecakapan kerja, yaitu: Pertama, faktor internal yakni faktor yang berasal dari dalam diri mahasiswa, yang meliputi kematangan fisik dan mental, kreativitas, minat, bakat, intelegensi, kemandirian, motivasi, dan penguasaan ilmu pengetahuan. Kedua, factor eksternal yakni factor yang berasal dari luar diri mahasiswa, yang meliputi peran masyarakat, keluarga, sarana dan prasarana perkuliahan, dan juga informasi dunia kerja. ${ }^{10}$ Dewa Ketut memiliki pandangan yang mirip dengan Kardimin tentang dua factor yang mempengaruhi kesiapan kerja lulusan, yaitu faktor eksternal dan internal. Selain yang sudah dijelaskan oleh Kardimin, Ketut menjelaskan bahwa faktor internal adalah sikap, kepribadian, nilai-nilai hidup atau filosofi hidup, penggunaan waktu senggang, pengalaman kerja, pengetahuan tentang dunia kerja, dan penampilan lahiriah. ${ }^{11}$ Kartini menjelaskan tentang faktor-faktor yang memengaruhi kecakapan kerja, yaitu faktor internal dan eksternal. Faktor internal atau faktor yang berasal dari dalam lulusan tersebut seperti: kecerdasan, keterampilan, bakat, minat, motivasi, dan kepribadian. Sedangkan faktor eksternal atau faktor dari luar lulusan itu sendiri adalah lingkungan keluarga, lingkungan dunia kerja, rasa aman dalam pekerjaannya, tersediannya kesempatan pengembangan diri, hubungan dengan pimpinan, dan gaji. ${ }^{12}$ Kedua faktor kecakapan kerja, yakni faktor internal dan eksternal perlu diupayakan secara serius oleh pengelola pendidikan tinggi teologi, untuk menghasilkan lulusan yang dapat menjawab kebutuhan pelayanan di Gereja dan lembaga pendidikan Kriten.

\section{Faktor Internal}

Beberapa faktor internal yang perlu ada pada diri setiap lulusan, sebagai prasyarat memasuki dunia pelayanan, di antaranya adalah keterampilan. Keterampilan merupakan kemampuan mengerjakan tugas. Keterampilan seseorang sangat terkait dengan kecakapannya dalam melakukan tugas yang dipercayakan kepadanya. Selain itu, kematangan fisik dan mental. Kematangan adalah situasi yang menghasilkan perubahan sikap sebagai akibat dari pertumbuhan dan perkembangan. Herminanto menjelaskan bahwa kesiapan mental untuk bekerja dipengaruhi oleh prestasi belajar dan pengalaman kerja setiap lulusan. ${ }^{13}$ Prestasi adalah penguasaan lulusan terhadap materi perkuliahan di bidangnya yang terkait dengan dunia pelayanan. Selanjutnya, ada minat, yakni unsur mental yang terdiri dari perasaan, harapan, rasa takut yang cenderung mengarahkan seseorang pada tujuan tertentu. Orang yang memiliki minat yang baik pada suatu bidang kerja akan mampu menyelesaikan pekerjaan tersebut dengan baik.

Berikutnya adalah bakat. Bakat adalah suatu kondisi kualitas yang dimiliki oleh seseorang yang memungkinkannya berkembang pada masa mendatang. Lalu, ada juga kecerdasan, yang mana setiap pribadi memilikinya secara berbeda-beda. Pribadi yang memiliki kecerdasan yang baik tentu akan lebih mudah dalam mengambil keputusan atau memecahkan masalah. Kemampuan intelegensi yang dimiliki tiap orang memegang peranan penting sebagai pertimbangan kesiapan seseorang masuk ke dalam dunia pelayanan. Selanjutnya, motivasi.

\footnotetext{
${ }^{10}$ Akhmad Kardimin, Strategi Melamar Kerja Dan Bimbingan Karier (Jakarta: Bumi Aksara, 2004).

${ }^{11}$ Dewi Ketut, Bimbingan Karir Di Sekolah-Sekolah (Ghalia Indonesia, 1993).

${ }^{12}$ Kartini, Menyiapkan Dan Memandu Karier (Jakarta: Rajawali Pers, 1991).

${ }^{13}$ Herminanto Sofyan, Kesiapan Kerja Siswa STM Di Jawa (Yogyakarta: IKIP Yogyakarta, 1992).
} 
Motivasi adalah perubahan eneri dalam diri (pribadi) seseorang yang ditandai dengan timbulnya perasaan dan reaksi untuk mencapai tujuan. Motivasi memiliki pengaruh yang sangat besar untuk mendorong lulusan untuk memasuki dunia kerja sehingga menciptakan kesiapan dari dalam dirinya untuk bekerja.

Ada pula sikap, yang dapat diartikan sebagai sebuah kesiapan yang dimiliki seseorang untuk bertindak secara positif terhadap permasalahan-permasalahan di dunia pelayanan. Sikap positif dari dalam individu tentang suatu pekerjaan akan mempengaruhi kesiapan individu dalam melakukan pekerjaan tersebut. Selanjutnya, kepribadian, yang merupakan peranan penting yang memiliki pengaruh terhadap penentu arah pilih jabatan dan kesiapan seseorang untuk melakukan suatu pekerjaan. Ada nilai-nilai hidup atau filosofi hidup. Nilai-nilai hidup adalah hal-hal penting dan berguna yang dianut seseorang yang berguna menimbulkan kesiapan kerja dalam dirinya. Terakhir, pengalaman pelayanan, yakni pengalaman pelayanan mahasiswa di gereja atau lembaga pendidikan Kristen selama berkuliah akan sangat memengaruhi caranya menghadapi permasalahan di dunia pelayanan.

Sepuluh faktor internal yang disebut di atas perlu dimiliki setiap lulusan, sehingga cakap dalam menjawab kebutuhan di dunia pelayanan gereja dan lembaga pendidikan Kristen. Faktor-faktor internal harus fokus pada pengembangan mahasiswa yang termuat dalam rumusan capaian pembelajaran, atau konkritnya dalam standar kompetensi pembelajaran. Berdasarkan survei yang telah dilakukan, ditemukan bahwa factor internal ini tidak menjadi target yang tertulis (tertulis di silabus atau kontrak perkuliahan). Beberapa dosen meyakini bahwa tujuan akhir seluruh pembelajaran yang telah dilakukan, secara otomatis akan menghasilkan factor-faktor internal yang bernilai baik. Hal ini tidak sepenuhnya salah, namun segala hal yang tidak tertulis secara jelas dalam silabus atau kontrak perkuliahan tidak mungkin menjadi target minimal capai pembelajaran.

\section{Faktor Ekternal}

Faktor eksternal adalah faktor yang sulit untuk dikondisikan dalam proses pembelajaran selama di kampus. Namun demikian, faktor ekternal memegang peranan dalam proses pengembangan para lulusan menjadi tenaga siap kerja di dunia pelayanan. Beberpa faktor eksternal yang menentukan kesiapan kerja dari tiap lulusan di antaranya adalah lingkungan keluarga. Keluarga merupakan lingkungan sosial yang kecil, namun demikian keluarga merupakan lingkungan yang paling menentukan dalam proses tumbuh kembang seorang pribadi. Kuantitas waktu yang besar dalam keluarga menjadi faktor penyumbang terbesar kepribadian seseorang. Rusnani dalam bukunya menjelaskan bahwa kondisi ekonomi keluarga berpengaruh besar dalam perkembangan anak. ${ }^{14}$ Harminanto mengatakan bahwa kesiapan kerja ditentukan oleh keadaan ekonomi orang tua, bimbingan social dari keluarga. ${ }^{15}$ Pengaruh dari latar belakang keluarga jelas terlihat pada dua tahun pertama dari setiap mahasiswa. Kehidupan berasrama selama kurang lebih 4 tahun telah menjadi ekosistem baru dalam membentuk nilai-nilai penting dalam kepribadian mahasiswa.

\footnotetext{
${ }^{14}$ Rusnani, "Pengaruh Kondisi Ekonomi Keluarga Terhadap Tingkat Keaktifan Anak Masuk Sekolah di SDN Pinggir Papas I Kec. Kalianget,” PERFORMANCE “ Jurnal Bisnis \& Akuntansi” (2013).

${ }^{15}$ Herminanto Sofyan, Kesiapan Kerja Siswa STM Di Jawa.
} 
Selain itu, lingkungan pelayanan. Lingkungan kerja atau pelayanan memiliki peran penting dalam proses pengembangan para lulusan. Sambutan yang hangat dari sesama pelayan dan perhatian pimpinan menjadi penting bagi tenaga kerja baru. Ardana dalam bukunya menjelaskan bahwa kondisi lingkungan kerja yang baik akan memacu kerja yang optimal dan nyaman, bahkan menjadikan pekerja bertahan dalam waktu yang lama. ${ }^{16}$ Respon lingkungan kerja yang kurang positif, jelas bukan sesuatu yang mudah untuk dihadapi para lulusan. Ada lulusan yang kemudian meninggalkan tempat pelayanan karena tidak dapat memenuhi tuntutan kebutuhan dari Gereja atau lembaga pendidikan Kristen tempatnya melayani. Hal inilah yang perlu dipikirkan oleh para pimpinan STT untuk membangun komunikasi kepada Gereja dan lembaga pendidikan Kristen agar berperan sebagai pengguna lulusan, dan sekaligus juga berperan sebagai partner dalam proses pengembangan lulusan.

\section{Kebutuhan Dunia Kerja}

Gereja sebagai lembaga rohani, sejatinya membutuhkan pelayan-pelayan dengan kompetensi yang baik. Pelayanan Gereja perlu disiapkan secara professional melalui pemilihan pelayan yang cakap. ${ }^{17}$ Dunia kerja memiliki kebutuhannya sendiri. Kebutuhan dunia kerja berbicara tentang kecakapan-kecakapan penting yang diperlukan dunia pelayanan dari tenaga kerja. Semakin baik kecakapan lulusan, maka akan memengaruhi tingkat produktivitas dan efektivitas kerja suatu lembaga atau dunia pelayanan. Permasalahan yang terjadi saat ini adalah, adanya disintegrasi antara dunia pendidikan dengan dunia kerja. Integrasi kompetensi lulusan dan kompetensi yang menjadi kebutuhan dunia kerja masih menjadi pekerjaan rumah penting yang perlu diselesaikan. Rendahnya tingkat relevansi pendidikan terhadap dunia kerja menjadi salah satu permasalahan pendidikan. ${ }^{18}$ Tidak terintegrasinya kedua bidang dengan baik, mengakibatkan bertambah besarnya permasalahan kebutuhan lulusan yang cakap di dunia pelayanan.

Proses pembelajaran di bangku kuliah bertujuan untuk mengembangkan potensi akademis dan kepribadian mahasiswa, menguasai ilmu pengetahuan dan teknologi, memiliki keterampilan yang sesuai dengan kebutuhan dan perkembangan di dunia pelayanan. Integrasi yang baik antara dunia pendidikan dan dunia kerja menghasilkan tenaga kerja yang menjawab kebutuhan pengguna tenaga kerja. Kesesuaian antara kebutuhan dan apa yang tersedia pada tenaga kerja, tentu akan meningkatkan kualitas dan kapasitas dunia kerja dan dunia pendidikan sendiri.

Pendidikan merupakan sarana strategis dalam pengembangan SDM sehingga penyelenggaraannya memerlukan penanganan secara cermat. Perlunya disesuaikan antara pengembangan dalam dunia pendidikan dengan kebutuhan dunia kerja. Ketidaksesuaian kecakapan lulusan dengan kebutuhan dunia kerja akan menciptakan pengangguran terdidik, dan pekerja yang tidak berkapasitas baik. ${ }^{19}$ Ini merupakan kerugian besar bagi dunia kerja, karena dunia kerja harus membeli tenaga kerja yang kurang memiliki kecakapan seperti yang diharapkan.

Berdasarkan riset yang berjudul "Relevansi Soft Skill yang Dibutuhkan Dunia Usaha dengan yang Dipelajari di Sekolah Menengah Kejuruan”, penelitian ini menggunakan 30

\footnotetext{
${ }^{16}$ Ardana, Managemen Sumber Daya Manusia (Yogyakarta: Graha Ilmu, 2012).

${ }^{17}$ Gidion, "Profesionalitas Layanan Gereja," Shift Key 7, no. 2 (2017): 89-104.

${ }^{18}$ Umar Tirtarahardja and La Sulo, "Pengantar Pendidikan," Rineka Cipta (2008).

${ }^{19}$ Joyoatmojo Soetarno, Pembelajaran Efektif: Upaya Peningkatan Kualitas Lulusan Menuju Penyediaan Sumber Daya Insani Yang Unggul (Surakarta: UNS Press, 2003).
} 
responden guru dan 30 responden siswa SMK. Hasil penelitian ini menunjukkan bahwa 6 urutan kebutuhan soft skill terpenting di dunia usaha adalah kemampuan berkomunikasi, kejujuran dan sikap perilaku yang baik, memiliki rasa tanggungjawab, disiplin waktu, kreatif dan banyak akal. Sebuah perusahaan otomotif terbesar di Indonesia yang berorientasi pada pasar internasional memiliki syarat utama dalam penerimaan karyawan barunya, yaitu mampu berkomunikasi dengan baik, mampu bekerja dengan tekanan kerja yang tinggi, sanggup bekerja lembur, memiliki kemampuan interpersonal skill yang baik, mampu bekerja mencapai target waktu yang ditetapkan, sehat jasmani dan rohani. ${ }^{20}$ Kesamaan dari dua sumber di atas menjelaskan bahwa dunia kerja membutuhkan lulusan yang cakap berkomunikasi, memiliki kepribadian yang baik, dan kreatif. Pelayanan di gereja dan lembaga pendidikan Kristen juga memerlukan lulusan dengan kecakapan yang serupa.

Sebuah riset berupa kuesioner tahun 1998 dilakukan untuk menentukan 5 keterampilan yang terpenting di dunia kerja pada Abad ke-21. Kuesioner yang ditanyakan tersebut terdiri dari 14 jenis keterampilan. Hasil riset tersebut menyimpulkan 5 jenis keterampilan yang paling dibutuhkan di dunia kerja diataranya adalah keterampilan komunikasi dan interaksi, bertindak berorientasi pada etika dan integritas, keterampilan mengelola perbedaan, keterampilan untuk memotivasi, kemampuan menjadi manajer yang strategis dan visioner. Selanjutnya dilakukan penelitian terhadap 3000 pengusaha, untuk mengetahui urutan factor yang paling penting sampai yang tidak penting dalam hal penerimaan karyawan. Terdapat 9 faktor yang diberikan untuk diurutkan oleh 3000 pengusaha tersebut. Berdasarkan hasil riset maka diurutkan peringkat dari factor yang paling penting hingga factor yang tidak penting. Dan tiga peringkat paling penting pertama adalah sikap (attitude), kedua adalah keterampilan komunikasi, dan ketiga adalah pengalaman kerja sebelumnya. ${ }^{21}$ Artinya, kecakapan yang dimiliki setiap lulusan sangatlah penting, baik berupa soft skills dan hard skill.

\section{Kebutuhan Soft Skill}

Ada banyak bentuk kecakapan yang menjadi kebutuhan dunia pelayanan. Para lulusan perlu mengerti bahwa kebutuhan dunia pelayanan terkadang berbeda dengan apa yang didapatkan di bangku pendidikan. Salah satu kecakapan penting yang perlu dimiliki adalah kecakapan soft skill yang mencakup kecakapan komunikasi, bahasa Inggris, dan kecakapan menyangkut personal attitude. Kemampuan soft skill adalah kemampuan memahami diri sendiri dan memahami orang lain. ${ }^{22}$ Soft skill adalah kemampuan seseorang dalam mengembangkan hubunganhubungan kemanusiaan. Beberapa cakupan meliputi: sikap berorientasi pada pencapaian, mempunyai inisiatif, kemampuan memimpin, percaya diri, fleksibel, berorientasi pada pelayanan, kemampuan membangun tim, dan lain sebagainya. ${ }^{23}$

Paul Murdoch mengatakan bahwa seorang lulusan perguruan tinggi harus dilengkapi dengan kecakapan soft skill berikut agar dapat bertahan dan unggul di dunia kerja, yaitu

\footnotetext{
${ }^{20}$ Anonimous, Lowongan Kerja (Jakarta: PT. Astra Internasional Tbk, 2013).

${ }^{21}$ Desmond Ginting, Komunikasi Cerdas; Panduan Komunikasi Di Dunia Kerja (Jakarta: PT Elex Media Komputindo, 2017).

${ }^{22}$ Murtaziqotul Khoiroh and Sucihatiningsih Dian Wisika Prajanti, "Pengaruh Motivasi Kerja, Praktik Kerja Industri, Penguasaan Soft Skill, dan Informasi Dunia Kerja terhadap Kesiapan Kerja Siswa SMK," Economic Education Analysis Journal (2019).

${ }^{23}$ Masim Vavai Sugianto, Persiapan Menghadapi Dunia Kerja (Salatiga: UKSW Press, 2015).
} 
kemampuan berbahasa Inggris; keterampilan komunikasi yang meliputi penguasaan computer dan internet, presentasi audio-visual, dan alat-alat komunikasi lainnya; keterampilan personal meliputi kemandirian, kemampuan men-dengar, keberanian, semangat, dan kemampuan kerjasama tim, inisiatif, dan keterbukaan. ${ }^{24}$ Pengetahuan bahasa Inggris menjadi penting secara khusus bagi para pemimpin gereja masa kini. Alasannnya, karena gelombang pengembangan ilmu teologi semakin cepat dan besar namun semua dalam sarana bahasa Inggris. Bahkan ada banyak penggunaan fasilitas canggih seperti smartphone, netbook, tablet, komputer, yang mendukung pelayanan gereja secara lebih efektif, di mana pengoperasiannya menggunakan bahasa Inggris.

Alfriani dan Rediana mengatakan dalam tulisannnya menegaskan bahwa kesuksesan seseorang dalam dunia kerja tidak hanya ditentukan oleh kemampuan hard skill, melainkan juga kemampuan soft skill yang menentukan seseorang dapat diterima dengan baik atau tidak. ${ }^{25}$ Kebutuhan dari dunia pelayanan tidak melulu soal prestasi akademik, tetapi juga kemampuan soft skill. Bahkan ada banyak riset-riset yang telah membuktikan bahwa kebutuhan dunia pelayanan terbesar terletak pada kebutuhan soft skill calon pelayan, dan bukan hanya pada kebutuhan hard skill-nya. Elfindri dalam bukunya mengatakan bahwa soft skill adalah semua sifat yang menyebabkan berfungsinya hard skill yang dimiliki dengan baik. Bahkan ada hasil riset tentang peran soft skill dalam kesiapan kerja lulusan SMK, dengan kesimpulan penelitian yaitu; terdapat pengaruh kemampuan soft skill terhadap tingkat kesiapan lulusan menghadapai dunia kerja sebesar 30,36 \%. ${ }^{26}$ Hard skill yang dimiliki seseorang lulusan yang menjadi berfungsi secara maksimal di dunia pelayanan, bilamana seorang lulusan memiliki kecakapan soft skill yang baik pula.

\section{Kebutuhan Hard Skill}

Hard skill merupakan suatu pengetahuan mayor dari kompetensi yang telah ditetapkan oleh suatu program studi. Hard skill yang dimiliki mahasiswa adalah berupa ilmu pengetahuan dan keterampilan sesuai bidang pendidikan. Sedangkan soft skill merupakan pengalaman mahasiswa selama mengikuti praktik pelayanan, kehidupan berasrama, berorganisasi, mengikuti ekstrakurikuler, dan pelatihan-pelatihan lainnya.

\section{Metode Penelitian}

Penelitian ini menggunakan pendekatan deskriptif kuantitatif untuk mengukur seberapa baik kecakapan lulusan STT dalam menjawab kebutuhan pelayanan di gereja dan lembaga pendidikan Kristen. Karena tujuan penelitian ini adalah memperoleh data apa adanya tentang nilai kecakapan lulusan STT dalam menjawab kebutuhan pelayanan di gereja dan lembaga pendidikan Kristen, maka pendekatan yang tepat adalah deskriptif kuantitatif. Pendekatan deskriptif kuantitatif berarti suatu pendekatan yang bertujuan menghasilkan gambaran apa adanya tentang fenomena yang ada, yang berlangsung pada masa tertentu atau saat yang telah

\footnotetext{
${ }^{24}$ Paul Mudroch, In The Sovreignty of Good (London: Rotledge \& Kegan, 1992).

25"Pengaruh Persepsi Siswa tentang Kompetensi Kejuruan, Penguasaan Soft Skill, dan Kematangan Karir terhadap Kesiapan Kerja Siswa Kelas XIIi Akuntansi SMK Negeri 2 Magelang Tahun Ajaran 2014/2015,” Economic Education Analysis Journal (2015).

${ }^{26}$ Elfindri, Softskill Untuk Pendidik (Jakarta: Baduose Media, 2011).
} 
lalu. ${ }^{27}$ Jenis penelitian deskriptif kuantitatif digunakan untuk memotret data apa adanya tentang berapa nilai kecakapan lulusan STT dalam menjawab kebutuhan pelayanan di Gereja dan lembaga pendidikan Kristen. Lulusan yang menjadi subyek penelitian adalah lulusan yang tahun masuknya dari tahun 2010-2014, berjumlah 30 orang. Sumber data atau penilai dalam penelitian ini adalah 30 orang gembala sidang atau pemimpin gereja, dan guru pamong yang bertugas memberikan penilaian kecakapan lulusan.

Instrumen penilaian yang digunakan adalah sebagai berikut: i) Mahasiswa memiliki perilaku dan karakter yang positif di pelayanan; ii) Mahasiswa memiliki motivasi yang baik dalam tugas pelayanan di Gereja; iii) Mahasiswa memiliki komunikasi yang baik dengan jemaat; iv) Mahasiswa memiliki pengetahuan yang baik tentang permasalahan teologis masa kini; v) Mahasiswa terus belajar untuk mengembangkan diri pengetahuan dan keterampilan pelayanan; vi) Mahasiswa memiliki keterampilan-keterampilan yang berguna dalam pelayanan di gereja/sekolah; vii) Mahasiswa dapat berkotbah/mengajar dengan baik dan benar; viii) Mahasiswa sudah memiliki pengalaman yang cukup menjadi pemimpin di gereja atau pengajar di sekolah; ix) Mahasiswa sudah dapat dipercaya menjadi salah satu pemimpin pelayanan di gereja; x) Mahasiswa memiliki kemampuan ber-bahasa inggris yang cukup baik. Adapun nilai reliabilitas instrument adalah 0,78, karena lebih besar dari nilai standar reliabilitas $(0,6)$ maka instrument ini dinyatakan reliable.

\section{Pembahasan}

\section{Hubungan Rentang Waktu di Tempat Penelitian dengan Kecakapan Lulusan}

Penyajian data dalam penelitian ini dibuat dalam tiga kelompok, kelompok pertama adalah data penilaian terhadap lulusan yang masuk sebagai mahasiswa dari tahun 2010-2012, kelompok kedua adalah lulusan yang masuk pada tahun 2013, dan kelompok ketiga adalah lulusan yang masuk pada tahun 2014. Pembagian kelompok ini hanya untuk memudahkan dalam proses perbandingan nilai ketiga kelompok lulusan, dalam menjawab rumusan masalah kedua yaitu; bagaimana perbandingan nilai tiap item pada masing-masing kelompok lulusan (sebelum 2013, 2013, 2014)? Secara keseluruhan perbandingan semua item, pada semua kelompok lulusan dapat dilihat sebagai berikut:

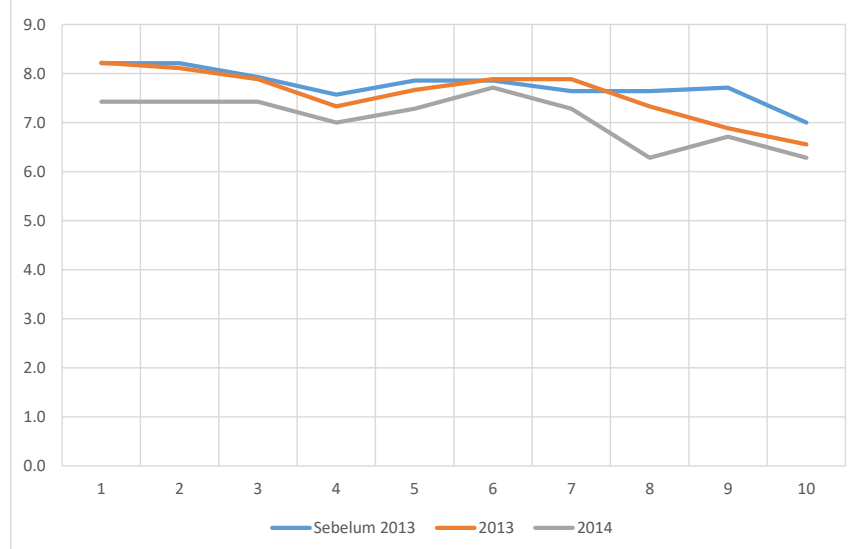

Gambar 1: Perbandingan Lama Melayani dengan Kecakapan Lulusan

\footnotetext{
${ }^{27}$ Sukmadinata dan Nana Syaodih, Metode Penelitian Pendidikan (Bandung: Remaja Rosdakarya, 2010).
} 
Dari data ini dapat dilihat bahwa penilaian kecakapan lulusan terhadap kelompok lulusan yang masuk "sebelum 2013" unggul pada item 1, 2, 3, 4, 5, 8, 9, dan item 10. Sedangkan kelompok lulusan yang masuk pada tahun "2013" unggul pada item 6 dan 7, dan selebihnya nilainya berada di bawah kelompok lulusan yang masuk "sebelum 2013". Sedangkan kelompok lulusan yang masuk pada tahun "2014", secara keseluruhan memiliki nilai kecakapan lulusan di bawah kelompok lulusan yang masuk "sebelum 2013" dan lulusan yang masuk pada tahun "2013". Berdasarkan data ini dapat disimpulkan bahwa kecakapan lulusan mengalami peningkatan setelah memiliki waktu yang lebih banyak di dunia pelayanan, hal ini tercermin dari nilai lulusan yang masuk di tahun 2014 yang jauh lebih rendah dari 2 kelompok lulusan yang sebelumnya. Hal ini juga memberikan bukti bahwa soft skill yang dibangun di STT terbukti mampu mendorong perubahan positif para lulusan di tempat praktik pelayanan.

\section{Perbandingan Kecakapan Lulusan}

Berdasarkan analisis data deskriptif pada 10 hal kecakapan lulusan, diperoleh perbandingan berikut:

Tabel 1: Perbandingan Kecakapan Lulusan pada 10 Item Pernyataan

\begin{tabular}{|l|l|c|c|c|c|}
\hline NO & ITEM & $\begin{array}{c}\text { Nilai } \\
\text { Mahasiswa } \\
2010-2012\end{array}$ & $\begin{array}{c}\text { Nilai } \\
\text { Mahasiswa } \\
2013\end{array}$ & $\begin{array}{c}\text { Nilai } \\
\text { Mahasiswa } \\
2014\end{array}$ & Rerata \\
\hline 1 & Kecakapan Prilaku dan Karakter & $82 \%$ & $82 \%$ & $74 \%$ & $80 \%$ \\
\hline 2 & $\begin{array}{l}\text { Kecakapan motivasi dalam } \\
\text { mengerjakan tugas dan tanggungjawab }\end{array}$ & $82 \%$ & $81 \%$ & $74 \%$ & $79 \%$ \\
\hline 3 & Kecakapan komunikasi & $79 \%$ & $79 \%$ & $74 \%$ & $77 \%$ \\
\hline 4 & Kecakapan pengetahuan teologi & $76 \%$ & $73 \%$ & $70 \%$ & $73 \%$ \\
\hline 5 & Kecakapan pengembangan diri & $79 \%$ & $77 \%$ & $73 \%$ & $76 \%$ \\
\hline 6 & $\begin{array}{l}\text { Kecakapan skill/keterampilan dalam } \\
\text { pelayanan }\end{array}$ & $79 \%$ & $79 \%$ & $77 \%$ & $78 \%$ \\
\hline 7 & Kecakapan berkotbah atau mengajar & $76 \%$ & $79 \%$ & $73 \%$ & $76 \%$ \\
\hline 8 & Kecakapan pengalaman pelayanan & $76 \%$ & $73 \%$ & $63 \%$ & $71 \%$ \\
\hline 9 & $\begin{array}{l}\text { Kecakapan sebagai pemimpin dalam } \\
\text { pelayanan }\end{array}$ & $77 \%$ & $69 \%$ & $67 \%$ & $71 \%$ \\
\hline 10 & Kecakapan ber-bahasa Inggris & $70 \%$ & $66 \%$ & $63 \%$ & $66 \%$ \\
\hline Rata-rata & $77,6 \%$ & $75,8 \%$ & $70,8 \%$ & $74,7 \%$ \\
\hline
\end{tabular}

Dari tabel dapat dilihat bahwa belum ada kecakapan yang mencapai nilai sempurna, yaitu 90100\%. Hal ini berarti 30 orang lulusan STT yang dinilai oleh penguuna lulusan dinyatakan belum menjawab kebutuhan dunia pelayanan (Gereja dan Lembaga Pendidikan Kristen) secara maksimal atau sempurna. Selain itu ada 5 kecakapan yang memiliki penilaian yang cukup rendah yaitu kecakapan ber-bahasa Inggris, kecakapan sebagai pemimpin dan pelayan, dan kecakapan pengalaman pelayanan, dan kecakapan pengetahuan teologi.

\section{Kesimpulan}

Kecakapan lulusan STT dalam menghadapi kebutuhan dunia pelayanan sudah cukup baik, namun belum maksimal atau sempurna dalam memenuhi kebutuhan pengguna lulusan. Kecakapan lulusan yang belum memuaskan perlu menjadi perhatian para pimpinan STT. 
Kecakapan lulusan juga sangat terkait dengan seberapa lama rentang waktu seorang lulusan bertugas di tempat pelayanan. Berdasarkan data ini dapat disimpulkan bahwa kecakapan lulusan mengalami peningkatan setelah memiliki waktu yang lebih banyak di dunia pelayanan, hal ini tercermin dari nilai lulusan yang masuk di tahun 2014, yang jauh lebih rendah dari 2 kelompok lulusan yang sebelumnya. Hal ini juga memberikan bukti bahwa soft skill yang dibangun di STT terbukti mampu mendorong perubahan positif para lulusan di tempat praktek pelayanan. Ada beberapa kecakapan lulusan yang penting, namun masih memiliki nilai yang rendah. Stidaknya terdapat 5 kecakapan yang memiliki penilaian yang cukup rendah yaitu kecakapan berbahasa Inggris, kecakapan sebagai pemimpin dan pelayan, dan kecakapan pengalaman pelayanan, dan kecakapan pengetahuan teologi. Hal ini perlu menjadi perhatian penting dari para pimpinan dan pengelola pendidikan di STT. Semua hasil penelitian ini juga dapat menjadi bahan pertimbangan bagi para pengelolan STT, untuk mengevaluasi prosesproses pembelajaran yang telah dilaksanakan.

\section{Referensi}

Anonimous. Lowongan Kerja. Jakarta: PT. Astra Internasional Tbk, 2013.

Ardana. Managemen Sumber Daya Manusia. Yogyakarta: Graha Ilmu, 2012.

Desmond Ginting. Komunikasi Cerdas; Panduan Komunikasi Di Dunia Kerja. Jakarta: PT Elex Media Komputindo, 2017.

Dewi Ketut. Bimbingan Karir Di Sekolah-Sekolah. Ghalia Indonesia, 1993.

Didik Suryanto, Waras Kamdi, Sutrisno. "Relevansi Soft Skill Yang Dibutuhkan Dunia Kerja Dengan Yang Dibelajarkan Di Sekolah Menengah Kejuruan.” Jurnal Teknologi dan Kejuruan 36, no. 2 (2013).

Elfindri. Softskill Untuk Pendidik. Jakarta: Baduose Media, 2011.

Gidion, Gidion. Profesionalitas Layanan Gereja. Shift Key: Jurnal Teologi dan Pelayanan, 2017, 7.2.

Herminanto Sofyan. Kesiapan Kerja Siswa STM Di Jawa. Yogyakarta: IKIP Yogyakarta, 1992.

Jansen Sinamo. Teologi Kerja Modern \& Etos Kerja Kristiani. Jakarta: Institut Darma Mahardika, 2011.

Joyoatmojo Soetarno. Pembelajaran Efektif: Upaya Peningkatan Kualitas Lulusan Menuju Penyediaan Sumber Daya Insani Yang Unggul. Surakarta: UNS Press, 2003.

Kardimin, Akhmad. Strategi Melamar Kerja Dan Bimbingan Karier. Jakarta: Bumi Aksara, 2004.

Kartini. Menyiapkan Dan Memandu Karier. Jakarta: Rajawali Pers, 1991.

Kellermann P and G Sagmeister. "Higher Education and Graduate Employment in Austria." European Journal of education 35, no. 2 (2000): 8.

Khoiroh, Murtaziqotul, and Sucihatiningsih Dian Wisika Prajanti. "Pengaruh Motivasi Kerja,

Praktik Kerja Industri, Penguasaan Soft Skill, dan Informasi Dunia Kerja Terhadap

Kesiapan Kerja Siswa SMK.” Economic Education Analysis Journal (2019).

Masim Vavai Sugianto. Persiapan Menghadapi Dunia Kerja. Salatiga: UKSW Press, 2015.

Paul Mudroch. In The Sovreignty of Good. London: Rotledge \& Kegan, 1992.

Rusnani. "Pengaruh Kondisi Ekonomi Keluarga terhadap Tingkat Keaktifan Anak Masuk

Sekolah di SDN Pinggir Papas I Kec. Kalianget.” PERFORMANCE “ Jurnal Bisnis \& Akuntansi" (2013).

Sukmadinata dan Nana Syaodih. Metode Penelitian Pendidikan. Bandung: Remaja

Rosdakarya, 2010.

Tirtarahardja, Umar, and La Sulo. "Pengantar Pendidikan.” Rineka Cipta (2008). 
Yorke, Mantz, and Peter T. Knight. "Curricula for Economic and Social Gain.” Higher Education (2006): 565-568.

"Pengaruh Persepsi Siswa tentang Kompetensi Kejuruan, Penguasaan Soft Skill, dan Kematangan Karir Terhadap Kesiapan Kerja Siswa Kelas XII Akuntansi SMK Negeri 2 Magelang Tahun Ajaran 2014/2015.” Economic Education Analysis Journal (2015). 